\author{
BEATA BOLESEAWSKA-LEWANDOWSKA \\ INSTYTUT SZTUKI, POLSKA AKADEMIA NAUK
}

\title{
ROMAN PALESTER I POLSKIE WYDAWNICTWO MUZYCZNE: KORESPONDENCJA W TRZECH ODSEONACH*
}

$R$ oman Palester (1907-89) w zapisie testamentowym przekazał swą spuściznę Archiwum Kompozytorów Polskich Biblioteki Uniwersyteckiej w Warszawie (AKP BUW). Tam też znajdują się, obok rękopisów muzycznych i różnego rodzaju dokumentów, zbiory bogatej korespondencji kompozytora. W większości są to listy do Romana Palestra, w niektórych tylko przypadkach uzupełnione o jego listy, najczęściej zachowane jako kopie maszynopisów bądź brudnopisy rękopiśmienne zapisane w notatkach kompozytora. Od jakiegoś czasu trwają starania o pozyskanie do zbiorów listów Romana Palestra znajdujących się w archiwach ich adresatów - w ten sposób udało się wzbogacić kolekcję o oryginały listów Andrzeja Panufnika (przekazane przez Lady Camillę Panufnik), a także Jerzego Katlewicza, Delfiny Ambroziak i Piotra Wierzbickiego. Jednocześnie udało się potwierdzić lokalizację kilku innych ważnych kolekcji listów Romana Palestra - listy do Kazimierza Wierzyńskiego przechowywane są w zbiorach bibliotek polskich w Paryżu i Londynie, do Gustawa Herlinga-Grudzińskiego w archiwum poety w Neapolu, a do Stanisława Skrowaczewskiego w Bibliotece Uniwersytetu w Minnesocie.

Funkcjonujące w ramach Gabinetu Zbiorów Muzycznych BUW Archiwum Kompozytorów Polskich od kilku lat działa aktywnie na rzecz promocji osoby i twórczości Romana Palestra, inicjując i wspierając powstawanie kolejnych wydawnictw płytowych, książkowych czy internetowych, jak i wydarzeń artystycznych i naukowych związanych z postacią twórcy. W ostatnim czasie przebadano także i wstępnie opracowano

* Artykuł powstał w ramach projektu badawczego Korespondencja Romana Palestra z Polskim Wydawnictwem Muzycznym (I945-I989), realizowanego w programie „Białe plamy - muzyka i taniec” finansowanym przez Instytut Muzyki i Tańca (edycja 2019/2020, projekt nr 208) przez zespół: Beata Bolesławska-Lewandowska, Magdalena Borowiec i Lech Dzierżanowski.

I Aktywność ta przyniosła szereg wymiernych rezultatów, jak m.in. uruchomienie portalu internetowego poświęconego kompozytorowi (www.palester.polmic.pl), współpraca przy publikacji niedokończonej autobiografii Romana Palestra, Stuch absolutny (Kraków 2018) przygotowanej do druku przez prof. Zofię Helman, znawczynię biografii i muzyki kompozytora oraz autorkę fundamentalnej pracy jemu 
korespondencję kompozytora z Polskim Wydawnictwem Muzycznym². I temu właśnie zbiorowi korespondencji chciałabym tutaj poświęcić więcej uwagi. Ukazuje ona bowiem kulisy kontaktów Romana Palestra z jego polskim wydawcą na przestrzeni wielu lat - od 1947 r., kiedy to kompozytor wyjechał z kraju do Paryża, jeszcze bez intencji pozostania na emigracji, aż po ostatnie lata jego życia. Jednocześnie korespondencja ta wpisuje się w szerszy kontekst sytuacji politycznej w PRL oraz mocno nią naznaczonych losów zarówno samego Palestra, jak i życia muzycznego w Polsce.

Ów kontekst staje się czytelny już w chwili, kiedy zobaczymy, że korespondencja dzieli się na trzy odrębne części odzwierciedlające okoliczności istotne z punktu widzenia historyczno-politycznych wydarzeń naszego kraju po II wojnie światowej. Pierwsza odsłona obejmuje przełom lat czterdziestych i pięćdziesiątych. To czas nieustalonej jeszcze do końca rzeczywistości, w której jednak wyraźnie zaznacza się wzmożenie nacisku politycznego na sztukę oraz coraz trudniejszy kontakt z twórcami pozostającymi poza granicami kraju. Ta część urywa się w roku I95I, kiedy już było jasne, że Palester pozostaje poza Polską, a w kraju skazano go na wymazanie ze zbiorowej pamięci. Odsłona druga to lata po odwilży październikowej - koniec lat pięćdziesiątych, kiedy wydawało się, że cenzura złagodniała, a urwane relacje z twórcami emigracyjnymi da się przywrócić bez narażania się władzom. Wkrótce okazało się to jednak znów niemożliwe, cenzura powróciła i wokół Palestra ponownie zaległa cisza. I wreszcie odsłona trzecia - to lata ostatnie, po zdjęciu zapisu cenzury na nazwisko kompozytora. Dokumentuje ona mozolne starania o przywrócenie jego muzyki krajowi w niełatwych latach osiemdziesiątych.

Przyjrzyjmy się bliżej tym trzem odsłonom korespondencji między Romanem Palestrem a Polskim Wydawnictwem Muzycznym.

I) Część pierwsza korespondencji obejmuje lata 1947-5I. Tworzy ją pięćdziesiąt sześć listów, przy czym tylko trzy z nich to kopie listów skierowanych do PWM przez kompozytora ${ }^{3}$, a reszta to listy z wydawnictwa do niego, głównie pisane przez Tadeusza Ochlewskiego, dyrektora PWM.

poświęconej (Roman Palester. Twórca i dzieto, Kraków 1999), a także aktywna współpraca przy publikacji serii monograficznych płyt kompaktowych z muzyką twórcy (do końca 2019 ukazało się ich siedem, głównie z muzyką kameralną, ale także np. z archiwalnymi nagraniami Requiem, Metamorfoz i Koncertu altówkowego ze zbiorów Związku Kompozytorów Polskich). W grudniu 2018 r. AKP BUW było, wraz z Uniwersytetem Muzycznym Fryderyka Chopina, współorganizatorem dwudniowej konferencji poświęconej Romanowi Palestrowi, a w październiku 2019 r. wraz z Fundacją Uniwersytetu Warszawskiego zorganizowało weekendowy festiwal muzyki kompozytora na Uniwersytecie Warszawskim.

2 Pracę tę wykonał zespół złożony z trzech osób: Magdaleny Borowiec, opiekującej się spuścizną Romana Palestra w AKP BUW, Lecha Dzierżanowskiego, inicjatora tej i wielu innych inicjatyw związanych z popularyzacją wiedzy o muzyce i życiu twórcy, oraz Beaty Bolesławskiej-Lewandowskiej, autorki prac naukowych na temat Romana Palestra i innych kompozytorów emigracyjnych. Por. przyp. *.

3 Mimo starań nie udało się odnaleźć oryginałów listów Romana Palestra do Polskiego Wydawnictwa Muzycznego. Wymieniane poniżej kopie jego listów zachowały się w zbiorach AKP BUW, czy to w wersji kopii maszynopisu (kalki maszynowe), czy też w rękopiśmiennej wersji brudnopisowej. Należy mieć nadzieję, że dalsze kwerendy w zbiorach PWM przekazanych do oddziału Archiwów Państwowych w Spytkowicach pozwolą na uzupełnienie omawianej kolekcji. 
W 1947 r. Roman Palester, mieszkający od marca 1945 r. w Krakowie, wyjechał wraz z żoną do Paryża, gdzie Barbara Palestrowa wykonywała prace zlecone jej przez PWM, a związane z promocją muzyki polskiej za granicą. Kompozytor pragnął natomiast skoncentrować się na pracy twórczej, bez intencji zrywania kontaktów z krajem. Długo jeszcze sądził, że taki model życia i pracy - tzn. życie w Paryżu, ale publikowanie partytur i wykonania muzyki (także zamówienia kompozytorskie) w Polsce - będzie możliwy do utrzymania. Co jakiś czas odwiedzał zresztą kraj, po raz ostatni w sierpniu i949 r., kiedy to wziął udział w symbolicznym już Zjeździe Kompozytorów i Krytyków Muzycznych w Łagowie Lubuskim (5-8 VIII I949 r.), wprowadzającym oficjalnie doktrynę socrealistyczną w zakresie muzyki. Wkrótce potem okazało się, że dłuższe utrzymywanie dotychczasowego status quo staje się niemożliwe, więc Palester zdecydował się ostatecznie na pozostanie na emigracji, przez co jego kontakty z krajem zostały radykalnie zerwane. Komunistyczne władze w Polsce przestały bowiem tolerować wspieranie emigracyjnych twórców. W konsekwencji Palester został usunięty ze Związku Kompozytorów Polskich, a PWM nakazano wycofanie jego już opublikowanych utworów oraz wstrzymanie prac wydawniczych nad kolejnymi. Dodatkowo na muzykę i nazwisko kompozytora wprowadzono zapis cenzury, obowiązujący oficjalnie do 1977 r. (z wyjątkiem lat odwilży po 1956 r., o czym będzie mowa niżej). Siłą rzeczy urwała się także wymiana listów Romana Palestra z Tadeuszem Ochlewskim i PWM - ostatnie listy tej części korespondencji pochodzą z lutego I95I r., potem kontakt zamiera.

Owa pierwsza część korespondencji obejmuje czas niezwykle ciekawy. Przełom lat czterdziestych i pięćdziesiątych w historii polskiego życia muzycznego to okres intensywnej odbudowy i tworzenia struktur organizacyjnych dla rozwoju muzyki i tu rola PWM była wielce znacząca. Jednocześnie, zwłaszcza po I949 r., uwidacznia się coraz większy, negatywny wpływ polityki, zmierzający także do ograniczenia kontaktów z zagranica. Widać to wyraźnie także w listach Tadeusza Ochlewskiego i Romana Palestra. Obraz ten byłby niewątpliwie pełniejszy, gdyby udało się odnaleźć listy kompozytora do PWM z tych lat - jednak kwerenda przeprowadzona w oddziale Archiwów Państwowych w Spytkowicach, gdzie przekazano dokumentację z archiwum PWM, nie przyniosła spodziewanego rezultatu. Wiadomo, że wcześniej listy Palestra były dostępne w PWM, korzystała z nich prof. Zofia Helman, pisząc swą monografię poświęconą kompozytorowi ${ }^{4}$, cytuje tam bowiem niektóre ich fragmenty. Najprawdopodobniej zatem podczas przekazywania materiałów archiwalnych do Spytkowic musiały one gdzieś zaginąć (brakuje także listów Barbary Palestrowej do PWM, choć wiadomo, że była ona w stałym kontakcie z Tadeuszem Ochlewskim i regularnie przesyłała mu sprawozdania ze swych działań dla PWM). 
Tym niemniej, z zachowanych listów Tadeusza Ochlewskiego do Romana Palestra wynika jasno kilka spraw, o których warto tu wspomnieć. Po pierwsze, kompozytor nie był łatwym partnerem do współpracy - co będzie zresztą widać także w dwóch kolejnych odsłonach jego korespondencji z PWM. Być może to sprawa naturalna, że kompozytorzy nie ułatwiają swym wydawcom pracy', w przypadku Palestra sprawę dodatkowo komplikował również jego przedłużający się pobyt w Paryżu i wynikające stąd coraz mniejsze zrozumienie kompozytora dla spraw krajowych i zmieniających się okoliczności politycznych. A że najwyraźniej niekiedy, pisząc do Ochlewskiego, nie przebierał w słowach, krytykując postęp prac nad swoimi partyturami oraz wysuwając szereg oczekiwań wobec PWM, reakcje dyrektora bywały równie ostre. Wyraźnie zirytowany Ochlewski, w liście z 24 VI 1948 r., odpowiadał zatem wprost:

Przestań nareszcie uważać siebie za jedynego kompozytora w Polsce i lekceważyć innych. Zdaj sobie wreszcie sprawę, że P.W.M. obarczone jest bardzo ważnymi innymi obowiązkami wydawniczymi, przede wszystkim w zakresie szkół muzycznych. Zupełnie przestałeś się orientować w hierarchii potrzeb muzyki polskiej ${ }^{6}$.

Zarzut o brak orientacji w sprawach polskich pojawia się zresztą w listach Ochlewskiego znacznie częściej, podobnie jak coraz wyraźniejszy żal do kompozytora, że zamiast włączyć się w pracę w kraju, zostawił kolegów i przedłuża swój pobyt we Francji. Już w 1947 r. Ochlewski pisał, tłumacząc narastające między nimi nieporozumienia:

[...] Że Twoje odejście określam jako małość, a nawet zdradę i że to nas oddaliło. I że to Twoja, a nie moja wina. Że zaobserwowałem absolutną obojętność do naszych spraw, dla naszych walk. Że Twoje odejście, słowem, nie było fair play: wiedziałeś, że jesteś potrzebny, że mogłeś jeśli tak potrzebny, że mogłeś pomóc, a nie „zechciało" Ci się i już. Że na Zachodzie nie znajdziesz nic nowego w sobie, bo tam - pospolitość, co obserwuję w rozmowach z ludźmi stamtąd ${ }^{7}$.

A w 1949 r. dodawał, wyjaśniając:

Twoja pozycja w kraju: mamy żal do Ciebie, że opuściłeś nas we wspólnej pracy w kraju. Wydaje się nam, że skoro Panufnik, Woytowicz, Malawski - w nawale pracy społecznej - mogą tworzyć, to mógłbyś i Ty. Warunki pracy Twojej nie byłyby gorsze od ich warunków, a pozwalają one na pisanie interesujących dzieł w kraju i na uczestnictwo w ruchu muzycznym (nie w „R.M.”!) ${ }^{8}$.

5 Znane mi, a niepublikowane dotąd, listy Andrzeja Panufnika do wydawnictwa Boosey\&Hawkes również nie są wolne od utyskiwań i nalegań w najdrobniejszych nawet kwestiach dotyczących wydań kolejnych partytur. Warto też zwrócić tu uwagę na opublikowaną niedawno dwutomową edycję korespondencji Witolda Lutosławskiego z wydawcami zagranicznymi, zob.: Witold Lutostawski Correspondence with his Western Publishers and Managers, red. Zbigniew Skowron, t. I-2, Kraków 2019.

6 Tadeusz Ochlewski do Romana Palestra, 24 VI 1948. Listy w zbiorach Archiwum Kompozytorów Polskich Biblioteki Uniwersyteckiej w Warszawie (dalej AKP BUW), bez sygnatury.

7 Tadeusz Ochlewski do Romana Palestra, 26 XI 1947, AKP BUW.

8 Tadeusz Ochlewski do Romana Palestra, 7 VI I949, AKP BUW. 
Mimo gorzkich słów, które są często obecne na kartach tych listów, nawet przez chwilę nie można mieć wątpliwości, że Tadeusz Ochlewski robił, co w jego mocy, aby tak długo, jak to było możliwe, wydawać w PWM utwory Romana Palestra9 ${ }^{9}$ W roku I949, kiedy kompozytor przyjechał do Polski, wydawało się nawet, że wszystko zmierza do tego, iż planuje on powrót. Nigdzie zresztą na przestrzeni tych lat nie ma mowy o emigracji, a śladem ogłoszenia decyzji Palestra o pozostaniu na Zachodzie (co miało miejsce latem I950 r. ${ }^{\circ}$ ) pozostaje jedynie końcowa wymiana listów, wyraźnie już dążąca do uporządkowania spraw wydawniczych. I9 XI I950 r. kompozytor pisze list, w którym wprost prosi o rozwiązanie większości dotychczasowych umów, na koniec dodając jednak:

Nie potrzebuję wyjaśniać[,] jak głęboko ubolewam nad koniecznością zerwania naszych stosunków wydawniczych, które następuje nie z mojej winy, ale nie wątpię ani na chwilę, że przyjdzie moment[,] w którym z największą radością będę mógł odnowić swoje stosunki z PWM ${ }^{\mathrm{II}}$.

Moment ten miał nadejść po kilku latach, w 1957 r., kiedy to w wyniku tzw. odwilży politycznej stosunki z twórcami emigracyjnymi zostały ponownie nawiązane. Wtedy też nadszedł czas na drugą odsłonę kontaktów Romana Palestra z Polskim Wydawnictwem Muzycznym.

2) Część druga korespondencji obejmuje lata 1957-65. Tworzy ją skromniejszy znacznie korpus czternastu listów. Jest wśród nich dwanaście pism z PWM oraz dwie kopie listów Romana Palestra.

Polityczne zmiany, które nastąpiły w Polsce pod koniec 1956 r., przyniosły także ocieplenie stosunków z emigracją. Władza komunistyczna otwarcie zachęcała artystów pozostających poza granicami Polski do powrotu do kraju, odmrożono także oficjalne kontakty z nimi. Środowisko muzyczne wykorzystało ten moment nie tylko na zainaugurowanie festiwalu Warszawska Jesień, lecz także na przywrócenie nazwisk

9 Podobnie zresztą postępował Zygmunt Mycielski, który w 1. I947-49, kiedy to pełnił najpierw funkcję sekretarza Zarządu Głównego, a następnie (od 1948 r.) Prezesa Związku Kompozytorów Polskich, pomagał Romanowi Palestrowi, prosząc go o przesyłanie do ZKP kompozycji, za które będzie mógł mu zapłacić. Zapewne właśnie w odpowiedzi na zachęty Mycielskiego, aby skomponował prosty „utworek dla ork. "odeonowskiej»" (list z 3 I I948, zachowany w AKP BUW, bez sygn.), Palester napisał w I948 r. Suitę weselną na orkiestrę odeonową.

IO 25 VIII 1950 r. w emigracyjnym Dzienniku Polskim i Dzienniku Żotnierza ukazała się oficjalna notka informująca o tym, że „Palester jest pierwszym wybitnym przedstawicielem sztuki zza żelaznej kurtyny, który wybrał "wolność»", cyt. za: Z. Helman, Roman Palester, s. I7I. Trudno powiedzieć, na ile to sam kompozytor ogłosił tę decyzję, a na ile po prostu nie dementował medialnych informacji. Z decyzją o pozostaniu na Zachodzie na pewno nosił się od dłuższego czasu, por.: Lech Dzierżanowski, „W poszukiwaniu «pastwiska» - amerykańskie plany Romana Palestra w świetle korespondencji kompozytora z Jerzym Fitelbergiem oraz Kazimierzem Wierzyńskim”, w: „American Dream”. Polscy twórcy za Oceanem, red. Beata Bolesławska-Lewandowska, Jolanta Guzy-Pasiak, Warszawa 2020 (= Muzyka Polska za Granicą 3), s. I39-152.

II Roman Palester do PWM, i9 XI 1950, kopia rękopisu w AKP BUW. 
i muzyki Romana Palestra czy Andrzeja Panufnika. Informacje o nich publikowano (początkowo dość ostrożnie) w prasie, a na afiszach koncertów w kraju wkrótce pojawić się miały ich kompozycje - włącznie z Warszawską Jesienią, gdzie w 1958 r. zaprezentowano najnowsza, IV Symfonię Palestra $^{\text {12}}$. Sytuacja sprzyjała także odnowieniu kontaktów PWM z kompozytorem.

Pierwszy list, dość formalny, wysłany został do Palestra 9 IV 1957 r. przez sekretarza wydawnictwa, Jana Paździorę. Zawierał on prośbę o nadesłanie informacji o utworach i działalności kompozytora w 1. 1948-56, a także aktualnego zdjęcia. Co ciekawe, zaadresowany został na adres redakcji paryskiej Kultury, choć kompozytor od I952 r. był pracownikiem polskiej sekcji rozgłośni Radia Wolna Europa w Monachium, o czym w Polsce doskonale wiedziano, jako że RWE słuchano w kraju, choć oczywiście nielegalnie. Najwyraźniej jednak nawet w okresie odwilży rozgłośnia ta postrzegana była jako bardziej niebezpieczny ze względów politycznych kontakt niż siedziba pisma redagowanego przez Jerzego Giedroycia. List w każdym razie do adresata trafił, co więcej on sam odpowiedział również używając adresu Kultury, musiała to być zatem świadoma taktyka.

Palestra wyraźnie ucieszyło ponowne nawiązanie kontaktu z Polską, chętnie wysłał potrzebne informacje, pytając przy tym o losy swych utworów wydanych przed laty w kraju. Odpowiedź na to zapytanie przesłał mu już sam Tadeusz Ochlewski, również rad z odnowienia relacji z kolegą. Odwzajemniając zapewnienia kompozytora o przyjaźni, potwierdził jednocześnie chęć zarówno wznowienia wydań dawnych jego kompozycji, jak i publikacji nowych. Dodał też, że przesłane przez Palestra informacje wykorzystane zostaną w II wydaniu Almanachu polskich kompozytorów wspótczesnych Bogusława Schaeffera, którego pierwsze wydanie ukazało się w roku 195 $6^{13}$. Nazwisko kompozytora - o czym Ochlewski nie wspomniał w liście - zostało w nim ujęte, mimo braku najnowszych informacji o jego aktywności twórczej. Do czasu II wydania natomiast, które ukazało się dopiero w 1966 r., sytuacja polityczna zmieniła się na tyle, że noty Palestra już w nim nie zamieszczono ${ }^{\mathrm{It}}$. $\mathrm{Z}$ początkiem lat

I2 Wykonała ją Orkiestra Filharmonii Narodowej pod dyrekcją Stanisława Skrowaczewskiego.

I3 Bogusław Schaeffer, Almanach polskich kompozytorów wspótczesnych, wyd. I, Kraków I956, wyd. II, Kraków 1966.

I4 W pierwszym wydaniu Almanachu pojawiły się nazwiska pozostających na emigracji Romana Palestra, Andrzeja Panufnika i Antoniego Szałowskiego, jednak w drugim wydaniu jedynie hasło dotyczące Panufnika zostało przepuszczone (przeoczone?) przez cenzurę. Roman Palester był tym faktem oburzony. W liście do Zygmunta Mycielskiego z 2 V I966 r. pisał: „[...] przysłano mi ostatnio jakiś 2-gi tom Leksykonu Kompozytorów Wspótczesnych Schäffera i jego współpracowników: figurują tam setki przeróżnych kompozytorów - niekiedy ze zgoła nieprawdziwego zdarzenia - tylko mnie nie ma. Cieszę się, że o Andrzeju [Panufniku] jest obszerny artykuł, ale tym gorsza jest krzywda moralna, bo przecież każdy powie, że jednak emigranci są uwzględnieni [...] Wiem, że to cenzura, ale mimo tego uważam, że Schäffer i Tomaszewski nie są w porządku” - list zachowany w Archiwum Zygmunta Mycielskiego Biblioteki Narodowej w Warszawie, sygn. II I4 386. W AKP BUW zachował się także brudnopis listu Romana Palestra do PWM w tej sprawie, nie wiadomo jednak, czy został on do wydawnictwa wysłany. 
sześćdziesiątych odwilż polityczna zaczęła bowiem ustępować zaciskającej się znów cenzurze, dla której Roman Palester, nawet nie tyle jako emigracyjny kompozytor, ile redaktor postrzeganego jako zdecydowanie wrogie systemowi komunistycznemu Radia Wolna Europa, był szczególnie niepożądany.

Tę zmianę linii politycznej widać i w listach od Ochlewskiego. Najpierw jednak następuje wymiana korespondencji omawiającej możliwości współpracy oraz wydań bądź wznowień kolejnych kompozycji. Znaczący jest także wątek wyjaśnień Ochlewskiego dotyczących zniszczenia materiałów nutowych utworów Palestra, które po ogłoszeniu informacji o jego pozostaniu na emigracji nakazano oddać na przemiał. Rozkaz ten wykonano w zajmującym się dystrybucją wydawnictw PWM „Domu Książki” (bez wiedzy wydawnictwa, jak zapewniał Ochlewski). Udało się uratować jedynie to, co zostało w „dyrektorskiej szafie” Ochlewskiego oraz w samej siedzibie PWM. Tadeusz Ochlewski starał się tę sytuację kompozytorowi wytłumaczyć, kwestia zniszczenia jego partytur była dla niego bowiem najwyraźniej szczególnie bolesna i chyba nie do końca zrozumiała. Mimo to, z obu stron widać znów przede wszystkim chęć współpracy, potwierdzanej zapewnieniami o wzajemnej przyjaźni i życzliwości. Dobrze obrazują je słowa Tadeusza Ochlewskiego, skreślone w liście z I5 X 1958 r.:

Kochany Romanie,

Odsuńmy na stronę wszystkie sztywności, które ostatnio zaistniały między nami. Nie powinny one mieć miejsca pomiędzy Palestrem a PWM. Przecież gdybyśmy się spotkali, to uściskalibyśmy się serdecznie i z żartem skwitowalibyśmy nasze wzajemne pretensje.

Życie biegnie wciąż naprzód. Jest skomplikowane. Istnieje mnóstwo różnych węzłów. Niektóre - niepotrzebne, zawikłane - trzeba po prostu przecinać. Kochany Romanie! Zwracam się do Ciebie z całą serdecznością i jak dawniej - z przyjaźniąis.

Wkrótce jednak miało się okazać, że wzajemna chęć do współpracy nie wystarczy, aby przezwyciężyć gromadzące się znów na horyzoncie polityczne chmury. Ich sygnałem staje się akapit zamieszczony w liście do kompozytora z 5 V 1959 roku. Czytamy w nim:

Jestem jednak zaniepokojony odwlekaniem przez Ministerstwo wyrażenia zgody na zawarcie z Tobą umowy wydawniczej. Lecz, nawet w najgorszym wypadku, z gotowych matryc sporządzimy kilka egz. partytur tymczasowego druku ${ }^{16}$.

Obawa ta okazała się prorocza, bowiem ani umowa, ani żadne z planowanych wówczas publikacji Palestra nie zostały zrealizowane. Urwała się też ponownie sama korespondencja. Ostatnim akcentem tej części listów pozostaje o sześć lat późniejszy, wysłany do Romana Palestra I5 VI 1965 r. list redaktorki PWM, Małgorzaty Karczyńskiej, z prośbą o nadesłanie aktualnego zdjęcia „w związku z wznawianiem przez nas Almanachu polskich kompozytorów wspótczesnych"17. Nie wiadomo, czy kompozytor

I5 Tadeusz Ochlewski do Romana Palestra, is X I958, AKP BUW.

I6 Tadeusz Ochlewski do Romana Palestra, 5 V I959, AKP BUW.

I7 Małgorzata Karczyńska (PWM) do Romana Palestra, Is VI I965, AKP BUW. 
spełnił tę prośbę, jednak nota o nim w II wydaniu tegoż almanachu i tak się nie pojawiła, o czym była już mowa ${ }^{18}$.

Na kolejny etap kontaktów między Romanem Palestrem a Polskim Wydawnictwem Muzycznym trzeba było zatem poczekać aż do czasu oficjalnego zniesienia zapisu cenzury na nazwisko kompozytora, co nastąpiło w 1977 r. ${ }^{19}$. Tadeusz Ochlewski jednak już tego nie doczekał, zmarł dwa lata wcześniej.

3) Część trzecia korespondencji Romana Palestra z PWM obejmuje lata I98I-89. Tworzy ją najobszerniejszy korpus sześćdziesięciu dziewięciu listów. Jest wśród nich czterdzieści dziewięć listów z PWM oraz dwadzieścia kopii listów Romana Palestra (w tym także zachowanych w jego notatkach brudnopisów listów do PWM).

Ostatnia część korespondencji między kompozytorem a jego polskim wydawcą jest nie tylko najobszerniejsza i najpełniejsza (dzięki zachowanym brudnopisom i kopiom listów kompozytora do PWM), lecz ma także odmienny od dwóch poprzednich charakter. Brak Tadeusza Ochlewskiego, mimo wszelkich nieporozumień zaprzyjaźnionego z Romanem Palestrem co najmniej od lat wojny, siłą rzeczy pozbawił ją akcentów osobistych, tak cennych zwłaszcza w listach z pierwszego okresu. Zarówno Mieczysław Tomaszewski, do 1988 r. stojący na czele PWM, jak i inni związani z wydawnictwem redaktorzy, którzy teraz pracować będą nad przygotowaniem partytur kompozytora do druku, traktowali go już bowiem inaczej - z szacunkiem należnym wielkiemu twórcy, przy jednoczesnym zachowaniu pełnego sympatii, ale jednak oficjalnego tonu. Inaczej też niż poprzednio, wymiana listów dotyczy obecnie większej liczby osób - obejmując poza siedzibą krakowską, także osoby związane z oddziałem warszawskim PWM (Adam Neuer, Jerzy Jasieński). O ile zatem w dawnych czasach to Tadeusz Ochlewski osobiście czuwał nad korespondencją z kompozytorem i nawet kiedy listy oficjalnie podpisywał np. sekretarz wydawnictwa Jan Paździora, jasne było, że ich treść dyrektor Ochlewski doskonale znał, teraz najwyraźniej praca wydawnictwa wyglądała zupełnie inaczej. Z Romanem Palestrem korespondować będą przede wszystkim redaktorki bezpośrednio zajmujące się przygotowywaniem jego partytur do publikacji, panie Wanda Gładysz i Ligia Pilecka, ponadto pozostający wciąż na swoim stanowisku Jan Paździora, zajmujący się sprawami umów, a także - od czasu do czasu - wspomniani już reprezentanci oddziału warszawskiego, do których należy też zaliczyć Zofię Helman, włączoną w opracowywanie wybranych kompozycji Romana Palestra do publikacji.

I8 Zob. przyp. I4.

I9 Inicjatorem podjęcia starań o wycofanie zapisu cenzury na nazwiska Romana Palestra i Andrzeja Panufnika był muzykolog Tadeusz Kaczyński, a pretekstem - planowane obchody pięćdziesiątej rocznicy utworzenia Stowarzyszenia Młodych Muzyków Polaków w Paryżu. Chciałabym w tym miejscu podziękować Profesor Zofii Helman za szczegółowy opis tych wydarzeń, przedstawiony przez nią w recenzji mojego dorobku habilitacyjnego. 
Sprawy poruszane w listach koncentrują się niemal wyłącznie na problemach wydawniczych. Uderzające są tu przy tym dwie kwestie - dokładność, by nie rzec drażliwość kompozytora, dotycząca wszystkich szczegółów publikacji jego kompozycji, zderzona z realiami powolnej, niekiedy może wręcz opieszałej pracy wydawnictwa (pamiętać jednak należy, że były to pod każdym względem niełatwe lata osiemdziesiąte). Zdarzało się bowiem, że niemal rok czekał na przesłanie mu do korekty partytur, w których nadal znajdował całkiem istotne błędy. Trudno się dziwić, że coraz częściej zauważał, że nie dane mu będzie doczekać ujrzenia ich opublikowanych wersji.

Zbliżający się z wolna do osiemdziesiątki kompozytor wiedział, że brakuje mu czasu. Nie rezygnował jednak w najmniejszym stopniu z dbałości o wszystkie detale, łącznie z kształtem nut i pauz, wersją tytułu, czasu trwania, zapisem tytułu i oznaczeń w kilku językach etc., zawsze prosząc o szczegółowe informacje. Jego wyjątkową niechęć budziły pomysły włączenia jego utworów w tzw. serie wydawnicze - długą dyskusję wywołała idea wydania jego Trenów do słów Jana Kochanowskiego oraz Trzech wierszy Czestawa Mitosza w serii nazwanej wstępnie „Muzyka polska na nowo odczytana”. Mimo że i Mieczysław Tomaszewski, i odpowiadający za kształt serii Zofia Helman i Adam Neuer przekonywali go, że będzie to wyłącznie z pożytkiem dla odbioru i dystrybucji jego utworów w Polsce; że jest to seria, w której przywołuje się kompozycje twórców niesłusznie zapomnianych, najczęściej ze względów pozamuzycznych (planowano tam umieszczenie także utworów m.in. Józefa Kofflera, Stanisława Wiechowicza czy Zygmunta Mycielskiego), jego stanowisko było nieprzejednane. W liście do Zofii Helman i Adama Neuera tłumaczył:

Szacunek[,] jaki żywię dla Obojga Państwa[,] nakazuje mi powiedzieć otwarcie, że jestem kategorycznie i najkompletniej przeciwny jakiejkolwiek „serii” mającej obejmować pozycje „na nowo odczytane”. W historii naszej muzyki nie ma - moim zdaniem - już nic do „rewindykowania”, a poza tym wszelkie „odczytywanie na nowo” jest całkowicie arbitralne i nie prowadzi do niczego.

Ponieważ jednak nie biorę żadnego udziału w krajowym życiu muzycznym, nie zamierzam zatem dyskutować na ten temat.

Ograniczę się zatem do stwierdzenia, że nie chciałbym widzieć w tej serii ani 3 wierszy Mitosza ani Trenów, ponieważ to są utwory względnie niedawne, a zatem nie mogą być „na nowo odczytywane”2o.

I pomimo iż ostatecznie nazwę serii zmieniono na „Muzyka polska XIX i XX wieku. Antologia”, Mieczysław Tomaszewski zapewnił w końcu twórcę, że jego kompozycje opublikowane zostaną poza serią, „jako edycje całkowicie «samodzielne»" ".

20 Roman Palester do Zofii Helman i Adama Neuera w odpowiedzi na ich list z dn. 19 VII 1985 r., kopia brudnopisowa, niedatowana, AKP BUW.

2I Mieczysław Tomaszewski do Romana Palestra, I2 V 1987, AKP BUW. Podkreślenie oryginalne. 
Niestety, miało do tego dojść dopiero po śmierci kompozytora i już nie za dyrekcji Tomaszewskiego, który w 1988 r. przeszedł na emeryturę ${ }^{22}$. Roman Palester przeczuwał, że tak może się stać. Dlatego też, ciesząc się z planów PWM co do publikacji swych kompozycji, a jednocześnie przeczuwając zbliżający się kres własnego życia, pisał w odpowiedzi Tomaszewskiemu:

W sumie jest to plan dość ekstensywny, na sporą ilość lat - w pewnym sensie są to po prostu "pobożne życzenia” testamentarne i zdaję sobie doskonale sprawę, że niewiele z tego - jeśli w ogóle - będę mógł zobaczyć. Ale chwilami wydaje mi się, że moja muzyka ma małą grupkę życzliwych przyjaciół, którzy będą posuwać sprawę naprzód i fakt, że Pana również mogę do niej zaliczyć[,] jest dla mnie źródłem głębokiej satysfakcji ${ }^{23}$.

Na pewno odnowienie kontaktów z Polską i perspektywa powrotu jego muzyki na krajowe estrady były dla Romana Palestra niezwykle ważne. W odniesieniu do ostatniej odsłony jego korespondencji z PWM warto jeszcze dodać, że nawiązany po latach milczenia kontakt między nim a wydawnictwem intensywnie wspierały dwie osoby, które w ostatnich latach życia twórcy połączyły z nim więzy przyjaźni. Mowa o Teresie Chylińskiej, która służyła pomocą również w roli posłańca, przewożąc osobiście z Paryża materiały od kompozytora dla PWM i odwrotnie, oraz o Zofii Helman, która pisała już wówczas pierwsze omówienia dzieł Palestra, a w przyszłości miała napisać monografię jego życia i twórczości ${ }^{24}$. Obie zostały depozytariuszkami spuścizny kompozytora, przekazując po jego śmierci cały zgromadzony w paryskim mieszkaniu dorobek do Biblioteki Uniwersyteckiej w Warszawie. Taka była ostatnia wola Romana Palestra, podobnie jak jego życzeniem było, aby jak najwięcej jego kompozycji znalazło się w katalogu PWM i aby dzięki temu jego muzyka była dostępna w Polsce i poza jej granicami ${ }^{25}$.

Trzy wiersze Czestawa Mitosza na sopran i I2 instrumentów (1975-77) w 1993 r., a Treny, trzy fragmenty z Jana Kochanowskiego na głos i zespół instrumentalny (1963, popr. 1973) w roku 1997. Mieczysław Tomaszewski przeszedł na emeryturę w 1988 r., na stanowisku dyrektora PWM zastąpił go Grzegorz Michalski.

23 Roman Palester do Mieczysława Tomaszewskiego, 2I VI 1987, kopia maszynopisu, AKP BUW.

24 Zob. przyp. 4.

25 W dyspozycji kompozytora wymienione są także cztery biblioteki, w których kompozytor pragnął widzieć swe partytury: Archiwum Kompozytorów Polskich Biblioteki Uniwersyteckiej w Warszawie, Biblioteka Jagiellońska w Krakowie, a także będące francuskim odpowiednikiem AKP BUW „Centre de Documentation de la Musique Contemporaine” w Neuilly sur Seine oraz Bibliotèque Nationale w Paryżu (wg kopii testamentu zachowanej w zbiorach AKP BUW, bez sygn.). 


\section{BIBLIOGRAFIA}

Dzierżanowski, Lech. „W poszukiwaniu "pastwiska» - amerykańskie plany Romana Palestra w świetle korespondencji kompozytora z Jerzym Fitelbergiem oraz Kazimierzem Wierzyńskim”. W: „American Dream”. Polscy twórcy za Oceanem, red. Beata Bolesławska-Lewandowska, Jolanta Guzy-Pasiak, I39-I52. Warszawa: Instytut Sztuki PAN, 2019 (= Muzyka Polska za Granicą 3).

Helman, Zofia. Roman Palester. Twórca i dzieto. Kraków: Musica Iagellonica, 1999.

Schaeffer, Bogusław. Almanach polskich kompozytorów wspótczesnych oraz rzut oka na ich twórczość. Kraków: PWM, ${ }^{\mathrm{I}} \mathrm{9} 956$.

Schaeffer, Bogusław. Almanach polskich kompozytorów wspótczesnych. Kraków: PWM, ${ }^{2} 1966$.

Skowron, Zbigniew, red. Witold Lutostawski Correspondence with his Western Publishers and Managers. T. I-2. Kraków: Musica Iagellonica, 2019.

\section{ROMAN PALESTER AND PWM EDITION: CORRESPONDENCE IN THREE STAGES}

Roman Palester's contacts with PWM Edition can be reconstructed based on correspondence which has survived as part of the composer's legacy deposited at the Archives of Polish Composers, kept at the University of Warsaw Library. These are mostly letters from representatives of the publisher to the composer, and in some cases also copies or rough drafts of the composer's own letters, which he preserved. This correspondence can be divided into three stages, which reflect the artist's contacts with the Polish publisher in the context of changing political circumstances: I) before his emigration was announced; 2) during the so-called political thaw following the Polish October (of 1956), and 3) in the last years of his life, when censorship of his name and works had been lifted. My paper discusses both the surviving correspondence and the main aspects of relations between Roman Palester and PWM Edition between 1947 and the composer's death, in the context of the political situation in Poland.

\section{Translated by Tomasz Zymer}

Słowa kluczowe / keywords: Roman Palester, Polskie Wydawnictwo Muzyczne / PWM Edition, korespondencja kompozytorów polskich / Polish composers' correspondence

Dr hab. Beata Bolesławska-Lewandowska, pracownik naukowy Instytutu Sztuki PAN w Warszawie. Autorka książek: Panufnik (200I), Górecki. Portret w pamięci (2013), Panufnik. Architekt emocji (2014), The Life and Works of Andrzej Panufnik (I9I4-199I) (2015), edycji korespondencji Zygmunta Mycielskiego i Andrzeja Panufnika (cz. I, 20I6) oraz zbioru rozmów o Zygmuncie Mycielskim (Mycielski. Szlachectwo zobowiązuje, 20I7). Autorka artykułów i recenzji na tematy związane z polską muzyką współczesną, publikowanych w pismach muzycznych i muzykologicznych w kraju i za granicą, a także tekstów na portalach internetowych, w programach koncertowych i książeczkach płytowych. Przewodnicząca Zarządu Sekcji Muzykologów oraz członek Zarządu Głównego Związku Kompozytorów Polskich.

bboleslawska@wp.pl 